University of Nebraska - Lincoln

DigitalCommons@University of Nebraska - Lincoln

Publications, Agencies and Staff of the U.S.

Department of Commerce

U.S. Department of Commerce

2011

\title{
Comparative metabolic rates of common western North Atlantic Ocean sciaenid fishes
}

\author{
A. Z. Horodysky \\ Hampton University, andrij.horodysky@hamptonu.edu \\ R. W. Brill \\ NOAA \\ P. G. Bushnell \\ Indiana University - South Bend \\ J. A. Musick \\ Virginia Institute of Marine Science \\ R. J. Latour \\ Virginia Institute of Marine Science
}

Follow this and additional works at: https://digitalcommons.unl.edu/usdeptcommercepub

Part of the Environmental Sciences Commons

Horodysky, A. Z.; Brill, R. W.; Bushnell, P. G.; Musick, J. A.; and Latour, R. J., "Comparative metabolic rates of common western North Atlantic Ocean sciaenid fishes" (2011). Publications, Agencies and Staff of the U.S. Department of Commerce. 281.

https://digitalcommons.unl.edu/usdeptcommercepub/281

This Article is brought to you for free and open access by the U.S. Department of Commerce at DigitalCommons@University of Nebraska - Lincoln. It has been accepted for inclusion in Publications, Agencies and Staff of the U.S. Department of Commerce by an authorized administrator of DigitalCommons@University of Nebraska - Lincoln. 


\title{
Comparative metabolic rates of common western North Atlantic Ocean sciaenid fishes
}

 \\ AND R. J. LATOUR* \\ *Department of Fisheries Science, Virginia Institute of Marine Science, College of William \& \\ Mary, Gloucester Point, VA, U.S.A., $\$$ Cooperative Marine Education and Research Program, \\ Northeast Fisheries Science Center, National Marine Fisheries Service, NOAA, Woods Hole, \\ MA, U.S.A. and §Department of Biological Sciences, Indiana University South Bend, \\ South Bend, IN, U.S.A.
}

(Received 17 March 2010, Accepted 27 April 2011)

\begin{abstract}
The resting metabolic rates $\left(R_{\mathrm{R}}\right)$ of western North Atlantic Ocean sciaenids, such as Atlantic croaker Micropogonias undulatus, spot Leiostomus xanthurus and kingfishes Menticirrhus spp., as well as the active metabolic rates $\left(R_{\mathrm{A}}\right)$ of $M$. undulatus and L. xanthurus were investigated to facilitate inter and intraspecific comparisons of their energetic ecology. The $R_{\mathrm{R}}$ of M. undulatus and L. xanthurus were typical for fishes with similar lifestyles. The $R_{\mathrm{R}}$ of Menticirrhus spp. were elevated relative to those of $M$. undulatus and L. xanthurus, but below those of high-energy-demand species such as tunas Thunnus spp. and dolphinfish Coryphaena hippurus. Repeated-measures non-linear mixed-effects models were applied to account for within-individual autocorrelation and corrected for non-constant variance typical of noisy $R_{\mathrm{A}}$ data sets. Repeated-measures models incorporating autoregressive first-order $[\mathrm{AR}(1)]$ and autoregressive moving average (ARMA) covariances provided significantly superior fits, more precise parameter estimates (i.e. reduced S.E.) and $y$ intercept estimates that more closely approximated measured $R_{\mathrm{R}}$ for M. undulatus and L. xanthurus than standard least-squares regression procedures.
\end{abstract}

Journal of Fish Biology (C) 2011 The Fisheries Society of the British Isles No claim to original US government works

Key words: intermittent-flow respirometry; metabolism; mixed-effects models; repeated measures; Sciaenidae.

\section{INTRODUCTION}

Energy acquisition and allocation are fundamental processes that integrate organismal physiology, behaviour and biophysics. Ingested energy is apportioned to metabolic requirements and wastes before surpluses can be routed to somatic and gonadal growth (Winberg, 1956; Hewett \& Kraft, 1993). Interest in the description, quantification and prediction of energy acquisition and allocation patterns of fishes has led to the development of bioenergetic and individual-based models (Kitchell et al., 1977; Boisclair \& Tang, 1993; Jobling, 1994). These models link physiology, behaviour

$\dagger$ Author to whom correspondence should be addressed at present address: Living Marine Resources Cooperative Science Center, Department of Marine and Environmental Science, Hampton University, Hampton, VA, U.S.A. Tel.: +1 757 728-6665; email: andrij.horodysky@hamptonu.edu 
and environmental conditions with population dynamics to provide system-level estimates of production and consumption (Kitchell et al., 1977; Brandt \& Hartman, 1993). Catabolism, generally the largest and most labile component of the energy budgets of fishes, must particularly be understood for such models to generate valid results (Boisclair \& Sirois, 1993; Ney, 1993).

Aerobic metabolism ranges from the standard metabolic rate $\left[R_{\mathrm{S}}\right.$, the rate of oxygen consumption $\left(M_{\mathrm{O}_{2}}\right)$ of an inactive, unfed, thermally acclimated subject at rest: Krogh, 1914; Brett \& Groves, 1979] to the upper limit set by maximum aerobic metabolic rate $\left(R_{\mathrm{A}}\right.$ : Fry, 1947). The $R_{\mathrm{S}}$ of fishes have been obtained using a variety of techniques, including repeated measurements on the same individual until a minimum rate of oxygen consumption is observed (Steffensen et al., 1994; Ferry-Graham $\&$ Gibb, 2001), regressing metabolic rate and swimming speed relationships back to zero activity to obtain the $y$-intercept (Brett, 1964; Muir et al., 1965) or via the use of paralytic agents to isolate minimum costs of organ function (Brill, 1979). More commonly, researchers measure routine or resting metabolic rates $\left(R_{\mathrm{R}}\right)$, which include the oxygen consumption of fishes exhibiting minor spontaneous activity (Beamish, 1964; Prosser, 1973). Active metabolic rate $\left(R_{\mathrm{A}}\right)$ is generally measured as the oxygen consumption at increments of enforced activity leading up to the maximum sustainable speed or after exhaustive exercise (Brett, 1965; Soofiani \& Priede, 1985).

Multiple environmental and biological factors influence the metabolic rates of fishes. The former include temperature and salinity (Hettler, 1976; Moser \& Hettler, 1989; Wuenschel et al., 2004), dissolved oxygen (Fitzgibbon et al., 2007) and photoperiod (Boef \& Le Bail, 1999; Jonassen et al., 2000). The interactive effects of temperature and dissolved oxygen have received considerable attention because of their spatial and temporal variability in aquatic systems (Taylor \& Peck, 2004). Biological factors affecting metabolic rates of fishes include body mass (Brett \& Groves, 1979; Clarke \& Johnston, 1999), ontogeny (Oikawa et al., 1991; Post \& Lee, 1996), life history (Metcalfe et al., 1995), individual disposition (McCarthy, 2001), stress (Barton \& Schreck, 1987) and nutritional condition (Alsop \& Wood, 1997). Additionally, the assimilation and biochemical transformation of food, termed specific dynamic action (SDA), elevate oxygen consumption and reduce the energy available to an organism for other activities (Beamish, 1974; Secor, 2009).

Comparative methods have provided novel insights into the form-functionenvironment relationships of teleost metabolic systems and how they affect behaviour (Metcalfe et al., 1995), habitat utilization (Chapman et al., 1995, 2002), distribution and movement (van Dijk et al., 1999), tolerance to environmental variables (MacIsaac et al., 1997; Pichavant et al., 2001), interspecific, intraspecific and predator-prey interactions (Morris \& North, 1984), aquaculture (Brougher et al., 2005) and bioenergetics (Hartman \& Brandt, 1995; Burke \& Rice, 2002). Despite the rich literature on teleost metabolic physiology (Clarke \& Johnston, 1999), however, such data are sparse for many managed neritic fishes such as teleosts of the family Sciaenidae that support valuable commercial and recreational fisheries along the U.S. east coast. Sciaenids occupy a myriad of habitats in freshwater, estuarine and reef-associated marine systems, but are most speciose in neritic waters, where species-specific ecomorphologies and microhabitats result in niche separation (Myers, 1960; Chao \& Musick, 1977). Temperature, salinity and dissolved-oxygen levels in estuaries used by sciaenids are highly variable (Breitburg, 2002). Previous studies have demonstrated that sciaenid fishes are good candidates for comparative study by 
virtue of their taxonomic, morphological and microhabitat diversity (Chao \& Musick, 1977; Horodysky et al., 2008a, b), but there has been little comparative study of their metabolic rates. This study therefore uses intermittent-flow respirometry to assess $R_{\mathrm{R}}$ in four sciaenid species and $R_{\mathrm{A}}$ and costs of transport $(C)$ in two species.

\section{MATERIALS AND METHODS}

\section{ANIMAL COLLECTION AND HUSBANDRY}

Experimental and animal care protocols were approved by the College of William and Mary's Institutional Animal Care and Use Committee and followed all relevant laws of the U.S. Atlantic croaker Micropogonias undulatus L. (1766), spot Leiostomus xanthurus Lacépède 1802, northern kingfish Menticirrhus saxatilis (Bloch \& Schneider 1801) and southern kingfish Menticirrhus americanus (L. 1758) were captured by hook and line (Table I). Animals were maintained in recirculating $1855 \mathrm{l}$ aquaria at mean \pm s.E. $15 \pm 1^{\circ} \mathrm{C}$ (winter) or $25 \pm 2^{\circ} \mathrm{C}$ (summer) and fed a combination of frozen Atlantic menhaden Brevoortia tyrannus (Latrobe 1802), squid Loligo sp. and commercially prepared food (AquaTox flakes; Zeigler; www.zeiglerfeed.com) (Table I). Prior to each trial, subjects were isolated and fasted for $48 \mathrm{~h}$ to ensure complete gastric evacuation. At the conclusion of each trial, wild subjects were tagged with a small plastic identification tag (Hallprint Pty Ltd; www.hallprint.com) and released to the captive research population.

\section{AUTOMATED INTERMITTENT-FLOW RESPIROMETRY}

Automated intermittent-flow respirometry was used to determine the $R_{\mathrm{R}}$ of four sciaenid species and the $R_{\mathrm{A}}$ of $M$. undulatus and L. xanthurus (Steffensen, 1989). In this technique, a respirometer, submerged in a flow-through outer bath, experiences repeated cycles of two computer-driven flow regimes over c. 36-48 h: flow-through chamber ventilation (5-10 min), when fresh sea water from the outer bath is flushed through the metabolic chamber, and closed-chamber $M_{\mathrm{O}_{2}}$ recording (5-60 min) intervals, where flushing ceases, effectively sealing the respirometer (Fig. 1). Accordingly, intermittent-flow respirometry eliminates wash-out problems of traditional flow-through respirometry and avoids the carbon dioxide and metabolite accumulation issues that plague closed respirometry (Steffensen, 1989). Furthermore, this computer-driven technique records metabolic rates with high temporal resolution over several days without the constant presence of a researcher, facilitating high data yields with reduced potential for human movement and noise biasing $M_{\mathrm{O}_{2}}$ upwards (Steffensen, 2002).

TABLE I. Species, sample size $(n)$ and individual mean (range in parentheses) mass $(M)$ of four sciaenid fishes investigated in (a) resting metabolic rate $\left(R_{\mathrm{R}}\right)$ and (b) active metabolic rate experiments

\begin{tabular}{lcc}
\hline Species & $n$ & $M(\mathrm{~g})$ \\
\hline (a) & & \\
Micropogonias undulatus & 42 & $254(30-790)$ \\
Leiostomus xanthurus & 39 & $90(4-240)$ \\
Menticirrhus saxatilis & 9 & $236(105-475)$ \\
Menticirrhus americanus & 6 & \\
(b) & & $27130-250)$ \\
Micropogonias undulatus & 15 & $121(55-480)$ \\
Leiostomus xanthurus & 12 &
\end{tabular}


(a)

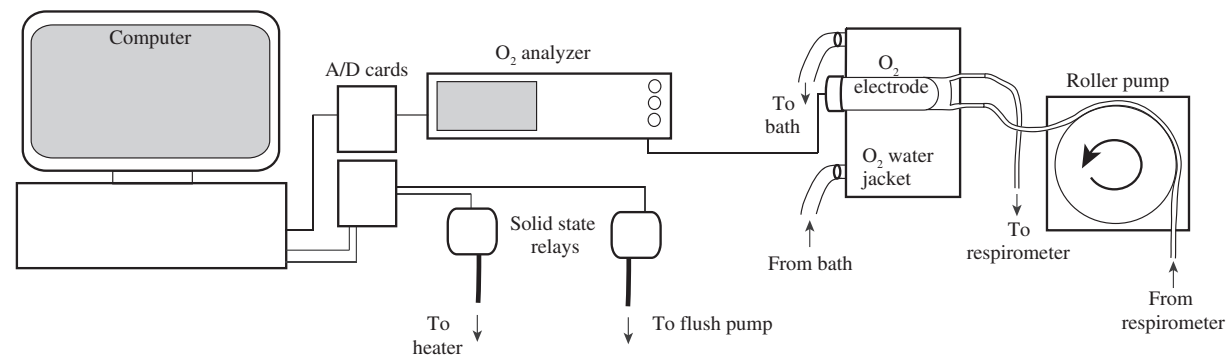

(b)

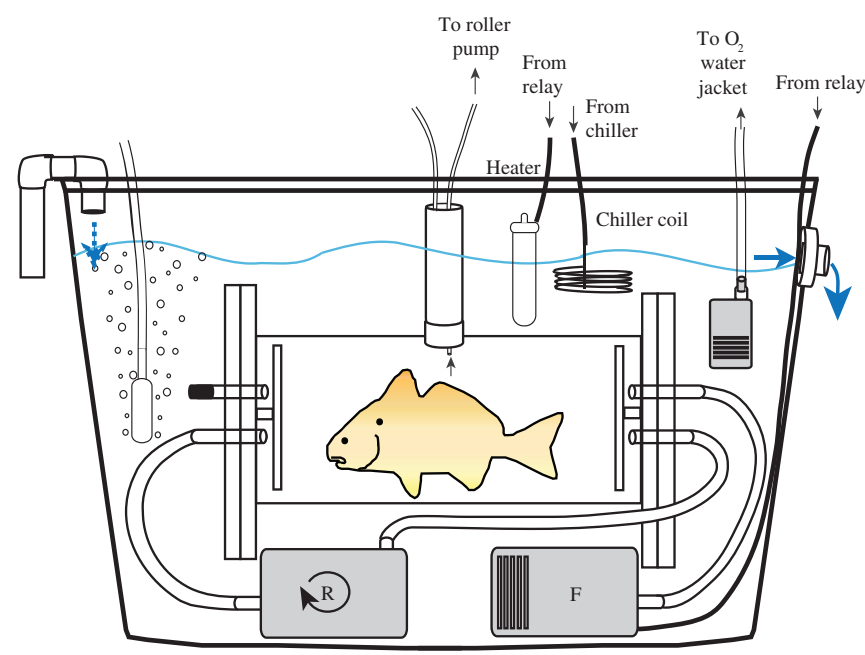

To or from roller pump

(c)

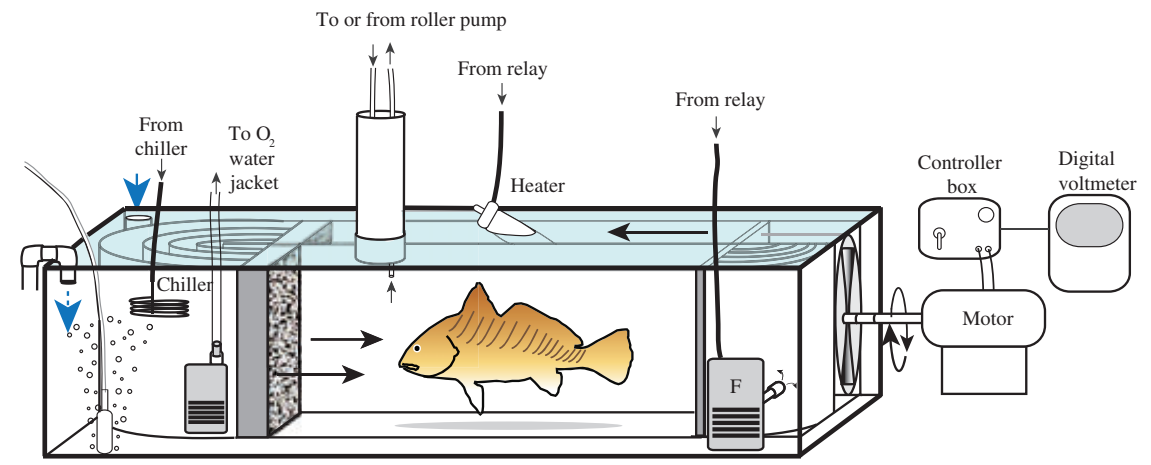

FIG. 1. Schematic representation of the metabolic chambers used in experiments. (a) Computing equipment and oxygen electrodes. (b) Experimental intermittent-flow respirometry chamber for resting metabolic rate $\left(R_{\mathrm{R}}\right)$ experiments (F, flushing pump; $\mathrm{R}$, recirculating pump); the species illustrated is Leiostomus xanthurus. (c) Experimental intermittent-flow Blažka swim chamber for active metabolic rate $\left(R_{\mathrm{A}}\right)$ experiments (F, the flush pump); the species illustrated is Micropogonias undulatus. Filtered, oxygenated sea water was introduced to the system via the spigot on the left of (b) and (c) $(-\rightarrow)$ and exited the system via through-hull fitting (b) or standpipe (c). 


\section{RESTING METABOLIC RATE}

The $R_{\mathrm{R}}$ were assessed as the $M_{\mathrm{O}_{2}}\left(\mathrm{mg} \mathrm{kg}^{-1} \mathrm{~h}^{-1}\right)$ of a thermally acclimated, unfed subject at low-level spontaneous motor activity. For each experiment (24-48 h), a subject was netted from its holding tank, weighed $(\mathrm{g})$ and transferred depending on body mass $(M)$ to a 0.35 or 7.401 acrylic respirometer (Loligo Systems; www.loligosystems.com) that was submerged in a flow-through outer bath [Fig. 1(b)]. Temperature-controlled, aerated and filtered sea water was delivered to the bath with an approximate system-wide turnover rate of $20-30 \% \mathrm{~h}^{-1}$ (Dowd et al., 2006). The $M_{\mathrm{O}_{2}}$ was measured during closed-respirometer intervals that were temporally adjusted until a subject extracted c. 20-30\% of the dissolved oxygen from the sea water. At predetermined intervals, the respirometer was flushed with fresh sea water by a small pump submerged in the outer bath, forcing the oxygen-depleted water through a PVC chimney to be re-aerated and mixed in the outer bath. During both recording and flushing cycles, water within the respirometer was continually mixed by a small recirculating pump external to the chamber (Steffensen, 1989). Flushing and recirculating flows were diffused by baffles within the respirometer and the entire assembly was covered with black plastic to minimize visual disturbance. Respirometer turnover rates were 200-500\% per flushing cycle. Collectively, $R_{\mathrm{R}}$ experiments were conducted at $10,15,20$ and $25^{\circ} \mathrm{C}$; when holding temperatures differed from experimental temperatures (difference $<5^{\circ} \mathrm{C}$ ), acclimation occurred at the rate of $c$. $1^{\circ} \mathrm{C} \mathrm{h}^{-1}$.

\section{CALCULATION OF OXYGEN UPTAKE}

The partial pressure of oxygen $\left(P_{\mathrm{O}_{2}}, \mathrm{~mm} \mathrm{Hg}\right)$ in respirometers was continuously measured with a polarographic electrode (Radiometer A/S; www.radiometer.dk) mounted in a water-jacketed cuvette (Loligo Systems) and connected to a digital oxygen meter (either Radiometer A/S or Cameron Instruments Company; www.cameroninstruments.com). Water temperature, time and $P_{\mathrm{O}_{2}}$ were oversampled, averaged to $1 \mathrm{~s}^{-1}$ to remove electronic noise, and recorded with a computerized data acquisition system by a custom Dasylab 7.0 worksheet interfacing with a QuattroPro 11.0 spreadsheet (www.adeptscience.co.uk). The $P_{\mathrm{O}_{2}}$ values were converted to oxygen content $\left(\mathrm{mg} \mathrm{O}_{2} \mathrm{1}^{-1}\right)$ for a given temperature and salinity following Richards (1965) and Dejours (1975). To help ensure the linearity of the rate of change of oxygen concentration with time, data from the first $60-180 \mathrm{~s}$ at the conclusion of the flush cycle were excluded from calculations. Oxygen uptake $\left(M_{\mathrm{O}_{2}}, \mathrm{mg} \mathrm{h}^{-1}\right)$ for a given measurement period was calculated from the time course of $P_{\mathrm{O}_{2}}$ change (Steffensen, 1984):

$M_{\mathrm{O}_{2}}=V \Delta P_{\mathrm{O}_{2}} \Delta t^{-1} \alpha^{-1}$, where $V$ is the respirometer volume (l) corrected for fish volume, $\Delta P_{\mathrm{O}_{2}} \Delta t^{-1}$ is the slope of the linear regression of $P_{\mathrm{O}_{2}}$ and time, and $\alpha$ is the oxygen solubility coefficient. The mass-specific $R_{\mathrm{R}}\left(\mathrm{mg} \mathrm{O}_{2} \mathrm{~kg}^{-1} \mathrm{~h}^{-1}\right)$ were calculated by dividing absolute $M_{\mathrm{O}_{2}}\left(\mathrm{mg} \mathrm{h}^{-1}\right)$ by the $M$ of the fish (in $\mathrm{kg}$ ).

After being placed in the respirometer, most individuals displayed elevated metabolic rates for $1-3 \mathrm{~h}$. These data were removed from analyses. Additionally, regressions of $P_{\mathrm{O}_{2}}$ and time with $r^{2}$ values $<0.9$ were excluded from consideration (Hölker, 2003). The $R_{\mathrm{R}}$ for each species were calculated by fitting a normal distribution to the frequency distribution of $M_{\mathrm{O}_{2}}$ measurements (Steffensen et al., 1994).

\section{$R_{\mathrm{R}}$ ANALYSES}

To investigate the effects of temperature on $M$. undulatus and L. xanthurus $R_{\mathrm{R}}$, power models were fitted via non-linear least squares to data for each species pooled across temperature and compared results to model parameterized with a temperature covariate (following Kimura, 2008). Model fits were evaluated using an information theoretic approach (Akaike, 1973; Burnham \& Anderson, 2002). As all experiments for both Menticirrhus species were conducted at $25^{\circ} \mathrm{C}$, models for those species instead were parameterized with species as a covariate rather than temperature. All $R_{\mathrm{R}}$ data were modelled assuming additive error:

$$
R_{\mathrm{R}_{i}}=a_{i} M_{i}^{b_{i}}+\varepsilon_{i}
$$


where for the $i$ th individual, $R_{\mathrm{R} i}$ is the resting metabolic rate, $M_{i}$ is body mass $(\mathrm{kg}), a_{i}$ is a constant, $b_{i}$ is the shape parameter, $\varepsilon_{i}$ is the error term, and $\left(\begin{array}{l}a_{i} \\ b_{i}\end{array}\right)=\left(\begin{array}{c}\beta_{0 a}+x_{i T} \beta_{T a} \\ \beta_{0 b}+x_{i T} \beta_{T b}\end{array}\right)$, where $T$ designates either the temperature or species group covariate. Fitting models using this approach summarizes information in a manner that functionally relates population parameters to covariates of interest, such as temperature or species group (Kimura, 2008). One interpretation of this approach is that the covariates make adjustments to underlying average model parameters, while an alternative is that the covariates partition the study population into subsets that have their own model parameters (Kimura, 2008). This approach enables model-based inference, straightforward significance testing of covariates and efficient comparisons of several model parameterizations on the basis of model fit. Model comparisons were conducted separately using an information theoretic approach following Akaike's information criterion (AIC; Akaike, 1973; Burnham \& Anderson, 2002):

$$
y=-2 \ln (\hat{L})+2 p,
$$

where $y=$ AIC, $\hat{L}$ is the estimated value of the likelihood function at its maximum and $p$ is the number of estimated parameters.

AIC is a parsimonious measure that strikes a balance between model simplicity and complex overparameterization (Burnham \& Anderson, 2002). Accordingly, AIC provided a quantitative metric to evaluate the simplest, most likely estimates given the data. All statistical analyses were conducted using the software package $R$ version 2.11.0 (R Development Core Team, 2010; www.r-project.org).

To place sciaenid data in context of other fishes, interspecific comparisons to other taxa were performed by first standardizing available oxygen consumption data from the experiments and the literature to absolute $M_{\mathrm{O}_{2}}\left(\mathrm{mg} \mathrm{O}_{2} \mathrm{~h}^{-1}\right)$, converting the oxygen consumption to $25^{\circ} \mathrm{C}$ where necessary via a global $Q_{10}$ of 1.65 for fishes (White et al., 2006) and regressing against $M(\mathrm{~kg})$. The $M_{\mathrm{O}_{2}}$ data of all species were allied graphically in three groups separated by energy demand, the end-members of which have been discussed by others (Brill, 1996; Fitzgibbon et al., 2007). These three groupings were used in analyses that applied AIC to compare the fits of a power model parameterized with all species pooled into one group against one with a categorical energy demand covariate (Kimura, 2008).

\section{ACTIVE METABOLIC RATE}

For $R_{\mathrm{A}}$ experiments, the fishes were weighed, total length $\left(L_{\mathrm{T}}\right)$ and standard lengths $\left(L_{\mathrm{S}}\right)$ were measured and then fishes were immediately transferred to a modified Blažka-type (Blažka et al., 1960) swimming respirometer [Fig. 1(c)]. Water temperature was maintained at $25 \cdot 0 \pm 0.9^{\circ} \mathrm{C}$, mean \pm S.E. Animals were allowed to acclimate to the chamber for $12 \mathrm{~h}$ with water velocity set to $0 \cdot 5$ body lengths $(\mathrm{BL}) \mathrm{s}^{-1}$ during which time $R_{\mathrm{R}}$ were measured as described previously. During swimming trials, water flow within the chamber was increased for $20 \mathrm{~min}$ that included a $10 \mathrm{~min}$ flushing (open) phase and a $10 \mathrm{~min}$ (closed) recording phase. Water velocity was increased every $20 \mathrm{~min}$, in steps that corresponded to 0.25 or 0.5 $\mathrm{BL} \mathrm{s}{ }^{-1}$ increments, until the subject was no longer able to continue sustained swimming and made contact with the rear chamber grate for $>3 \mathrm{~s}$ twice within the same swimming speed measurement interval.

For $R_{\mathrm{A}}$ experiments, the relationship between swimming speed and $M_{\mathrm{O}_{2}}$ was investigated by fitting power functions of the form

$$
M_{\mathrm{O}_{2}}=a+b U^{c}
$$

where $a, b$ and $c$ are constants and $U$ is the swimming speed $\left(\mathrm{BL} \mathrm{s}^{-1}\right)$. The $R_{\mathrm{S}}$ were estimated by extrapolating the $M_{\mathrm{O}_{2}}$ relationship back to a constant $U$ of $0 \mathrm{BL} \mathrm{s}^{-1}$ (i.e. the constant $a$ 
in equation 1) (Dewar \& Graham, 1994). Maximum metabolic rate $\left(R_{\mathrm{A}}\right)$ was defined as each individual's metabolic rate at maximum swim speed.

Active metabolic rate experiments in which the oxygen consumption of a swimming individual is recorded repeatedly at increasing $U$ may violate several fundamental assumptions of standard non-linear regression, including independence and constant variance (i.e. homoscedasticity) (Underwood, 2002). To consider each $M_{\mathrm{O}_{2}}$ measurement as independent within subjects is tantamount to pseudoreplication (Hurlbert, 1984); doing so may lead to biased parameter estimates (i.e. intercept, slope and shape parameters), s.E. and metrics of model fit (Littell et al., 2006). Furthermore, $R_{\mathrm{A}}$ measurements may be more variable among subjects at higher $v$. lower $U$, resulting in violation of the regression assumption of homoscedasticity. Repeated-measures non-linear mixed-effects models that considered the within-individual autocorrelation (package nlme; Pinheiro \& Bates, 2004) and weighted the data by the inverse of the variance at each level of the $x$-variable $\left(\mathrm{BL} \mathrm{s}^{-1}\right)$ were therefore fitted to the sciaenid $R_{\mathrm{A}}$ data to account for repeated sampling of individuals, heteroscedastic variance and nonnormally distributed error terms that violate regression assumptions of standard and mixed models. These mixed models contained fixed $(U)$ and random variables (fishes). Subjects were a random sample from the wild population, thus 'fish' was modelled as a random variable. For each species, the best fitting covariance structure was objectively selected using an information theoretic approach (Burnham \& Anderson, 2002) following AIC.

The costs of transport $(C)$ and optimum swimming speeds $\left(U_{\text {opt }}\right)$ were calculated separately for $M$. undulatus and $L$. xanthurus from the $R_{\mathrm{A}}$ model parameters and $M_{\mathrm{O}_{2}}$ data following Claireaux et al. (2006) and Videler (1993). For each individual, $M_{\mathrm{O}_{2}}$ at each $U$ was converted from mg $\mathrm{O}_{2} \mathrm{~kg}^{-1} \mathrm{~h}^{-1}$ to $\mathrm{J} \mathrm{kg}^{-1} \mathrm{~h}^{-1}$ using an oxycalorific coefficient of $13.6 \mathrm{~J} \mathrm{mg} \mathrm{O}_{2}^{-1}$ (Elliott \& Davison, 1975). Gross costs of transport $\left(C_{\mathrm{G}} ; \mathrm{J} \mathrm{kg}^{-1} \mathrm{~km}^{-1}\right)$ were determined by dividing each $M_{\mathrm{O}_{2}}$ by the $U\left(\mathrm{BL} \mathrm{s}^{-1}\right)$ at which it was obtained and cancelling time units. A predictive line was calculated using the equation

$$
C_{\mathrm{G}}=\hat{a} U^{-1}+\hat{b} U^{(\hat{c}-1)} .
$$

Net costs of transport $\left(C_{\mathrm{N}} ; \mathrm{J} \mathrm{kg}^{-1} \mathrm{~km}^{-1}\right)$ were determined by subtracting the $R_{\mathrm{S}}$ from each $M_{\mathrm{O}_{2}}$, dividing by the $U\left(\mathrm{BL} \mathrm{s}^{-1}\right)$ at which it was obtained, cancelling time units and plotting. Using parameter estimates from the best fitting power model, a predictive line was calculated from the equation

$$
C_{\mathrm{N}}=\hat{b} U^{(\hat{c}-1)}
$$

The optimum swimming speed $\left(U_{\mathrm{opt}} ; \mathrm{BL} \mathrm{s}{ }^{-1}\right)$ was calculated according to the following equation:

$$
U_{\mathrm{opt}}=\left\{\hat{a}[(\hat{c}-1) \hat{b}]^{-1}\right\}^{\hat{c}-1}
$$

Finally, $C_{\mathrm{Nmin}}$ and $C_{\mathrm{Gmin}}$ were calculated by inserting the $U_{\mathrm{opt}}$ for each species into equations (4) and (5) and cancelling time units.

\section{RESULTS}

The $R_{\mathrm{R}}$ of $M$. undulatus and $L$. xanthurus increase with $M$ and temperature (Fig. 2 and Tables II and III). On the basis of $\triangle$ AIC values, the inclusion of temperature as a covariate resulted in substantially better fits to the $M$. undulatus and L. xanthurus $R_{\mathrm{R}}$ data than pooled models ignoring temperature (Table III). The null 


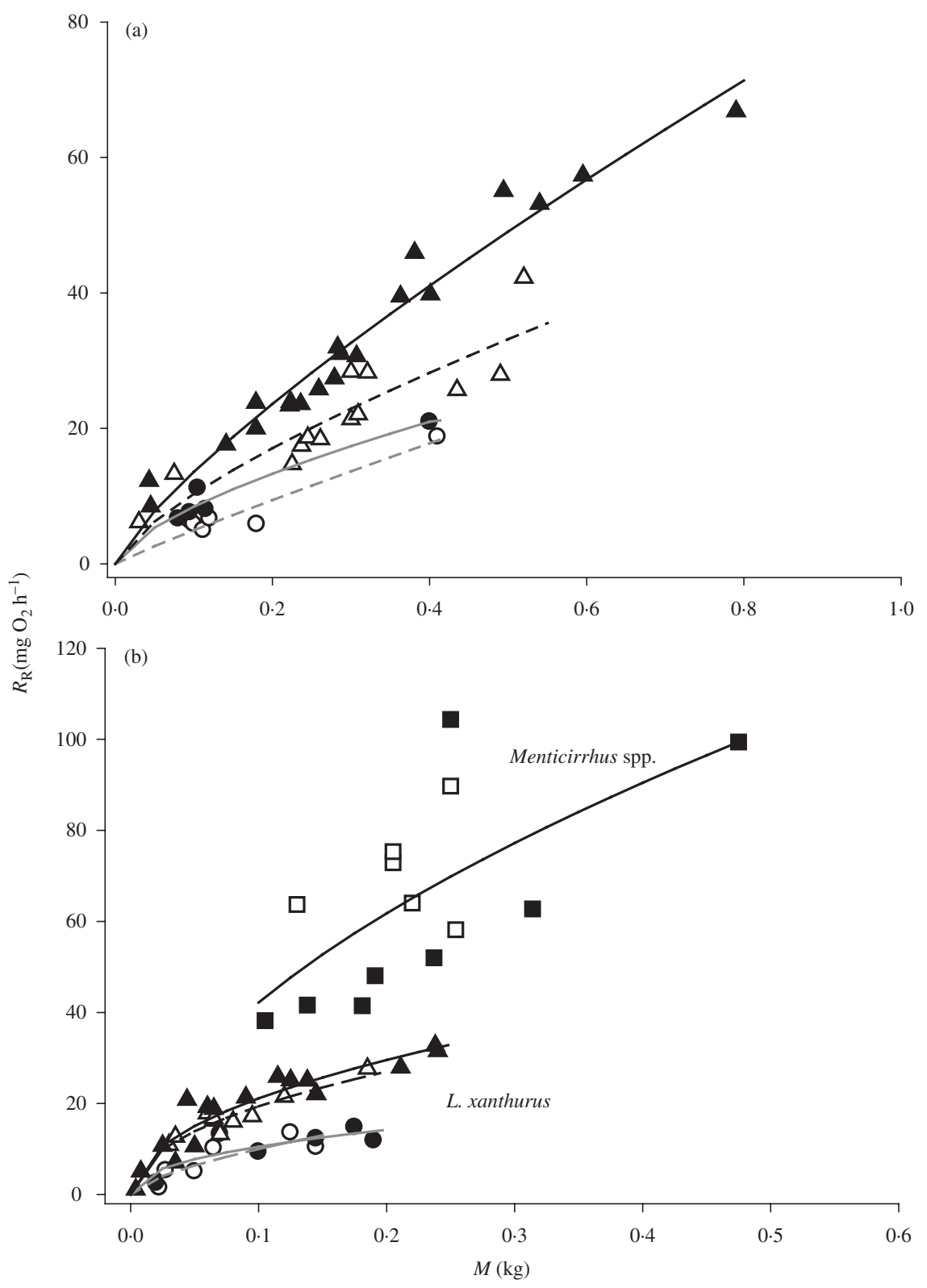

FIG. 2. Best fitting power equations (Tables II and III) fitted to the resting metabolic rates $\left(R_{\mathrm{R}}\right)$ of (a) Micropogonias undulatus and (b) Leiostomus xanthurus and Menticirrhus spp. For M. undulatus and L. xanthurus: at $10^{\circ} \mathrm{C}(-\circ), 15^{\circ} \mathrm{C}(\bullet), 20^{\circ} \mathrm{C}\left(-\Delta_{-}\right)$and $25^{\circ} \mathrm{C}\left(\bullet_{-}\right)$. For Menticirrhus spp.: Menticirrhus saxatilis $(\square)$ and Menticirrhus americanus ( $\square$ ). The power function (_) is for the model pooling both species (best fit; Tables II and III).

model (pooled temperatures) received no empirical support. Estimates of the constant $a$ in power functions fitted to each temperature separately for each species generally increased with temperature $\left(M\right.$. undulatus mean $Q_{10}=1 \cdot 76$, L. xanthurus mean 
TABLE II. Parameter estimates resulting from fitting power models parameterized to investigate the effects of temperature to resting metabolic rate $\left(R_{\mathrm{R}}\right)$ data using the approach described by Kimura (2008). Subscripts in the parameter column refer to temperature $\left(T,{ }^{\circ} \mathrm{C}\right)$ or species (sp., NK = Menticirrhus saxatilis, SK = Menticirrhus americanus). For pooled models, s.E. are presented for the estimates. For Kimura models, values in the estimates column are presented as the difference from the reference group (R), and S.E. captures the precision of the change from the reference group for a given covariate level. $P$-values are associated with tests evaluating whether each parameter estimate is statistically different from zero. $\triangle \mathrm{AIC}$ was calculated by subtracting each model's AIC from the best fitting model's AIC ( $\triangle \mathrm{AIC}=$ 0 denotes best fit). Models with $\triangle \mathrm{AIC}<2$ have strong support, those with $\Delta \mathrm{AIC}>10$ have little to no support (Burnham \& Anderson, 2002). Bold AIC values indicate the best fitting models

\begin{tabular}{|c|c|c|c|c|c|c|}
\hline Species & Parameter & Estimate \pm s.E. & $t$ & $P$ & AIC & $\Delta \mathrm{AIC}$ \\
\hline Micropogonias undulatus & $\begin{array}{c}\text { Pooled }_{\mathrm{T}} \\
a \\
b \\
\text { Kimura }_{\mathrm{T}} \\
a_{10}(\mathrm{R}) \\
a_{15} \\
a_{20} \\
a_{25} \\
b_{10}(\mathrm{R}) \\
b_{15} \\
b_{20} \\
b_{25}\end{array}$ & $\begin{aligned} 83 \cdot 18 & \pm 7.09 \\
0.95 & \pm 0.08 \\
& \\
41.33 & \pm 15 \cdot 66 \\
-3.05 & \pm 19.47 \\
13.47 & \pm 17 \cdot 17 \\
43.94 & \pm 16 \cdot 10 \\
0.92 & \pm 0.27 \\
-0.26 & \pm 0.33 \\
-0.20 & \pm 0.29 \\
-0.12 & \pm 0.27\end{aligned}$ & $\begin{array}{r}2.64 \\
-0.16 \\
0.79 \\
2.73 \\
3.44 \\
-0.81 \\
-0.67 \\
-0.45\end{array}$ & $\begin{array}{l}<0 \cdot 001 \\
<0 \cdot 001 \\
<0 \cdot 05 \\
>0 \cdot 05 \\
>0 \cdot 05 \\
<0.05 \\
<0 \cdot 01 \\
>0 \cdot 05 \\
>0 \cdot 05 \\
>0.05\end{array}$ & $299 \cdot 4$ & $56 \cdot 7$ \\
\hline Leiostomus xanthurus & $\begin{array}{c}\text { Pooled }_{\mathrm{T}} \\
a \\
b \\
\text { Kimura }_{\mathrm{T}} \\
a_{10}(\mathrm{R}) \\
a_{15} \\
a_{20} \\
a_{25} \\
b_{10}(\mathrm{R}) \\
b_{15} \\
b_{20} \\
b_{25}\end{array}$ & $\begin{aligned} 56 \cdot 84 & \pm 11.10 \\
0.52 & \pm 0.09 \\
44.49 & \pm 26.43 \\
-15.75 & \pm 29 \cdot 16 \\
14.02 & \pm 29.48 \\
20 \cdot 12 & \pm 27.33 \\
0.65 & \pm 0.25 \\
-0.21 & \pm 0.32 \\
-0.17 & \pm 0.26 \\
-0.16 & \pm 0.25\end{aligned}$ & $\begin{array}{r}1.68 \\
-0.54 \\
0.48 \\
0.74 \\
2.61 \\
-0.66 \\
-0.63 \\
-0.64\end{array}$ & $\begin{array}{l}<0.001 \\
<0.001 \\
>0.05 \\
>0.05 \\
>0.05 \\
>0.05 \\
<0.05 \\
>0.05 \\
>0.05 \\
>0.05\end{array}$ & $246 \cdot 3$ & $47 \cdot 7$ \\
\hline Menticirrhus spp. & $\begin{array}{c}\text { Pooled }_{\text {sp }} \\
a \\
b \\
\text { Kimura }_{\mathrm{sp}} \\
a_{\mathrm{NK}}(\mathrm{R}) \\
a_{\mathrm{SK}} \\
b_{\mathrm{NK}} \\
b_{\mathrm{SK}}\end{array}$ & $\begin{aligned} 149.71 & \pm 38.55 \\
0.55 & \pm 0.18 \\
166.05 & \pm 45.79 \\
-71.89 & \pm 79.66 \\
0.68 & \pm 0.21 \\
-0.50 & \pm 0.48\end{aligned}$ & $\begin{array}{r}3.62 \\
-0.90 \\
3.31 \\
-1.03\end{array}$ & $\begin{array}{l}<0 \cdot 01 \\
<0 \cdot 01 \\
<0 \cdot 01 \\
>0 \cdot 05 \\
<0 \cdot 01 \\
>0 \cdot 05\end{array}$ & $122 \cdot 2$ & $0 \cdot 6$ \\
\hline
\end{tabular}

$\left.Q_{10}=1.78\right)$, but the scaling parameter $b$ did not. Parameter estimates for L. xanthurus at 10 and $15^{\circ} \mathrm{C}$ were imprecise due to high variability in measured $R_{\mathrm{R}}$ values and low sample size. On the basis of $\triangle \mathrm{AIC}$ values, a model parameterized with a 
TABLE III. Summary of $R_{\mathrm{R}}$ equations for Micropogonias undulatus and Leiostomus xanthurus fitted separately to temperatures, and pooled for Menticirrhus spp. S.E. are reported in parentheses following parameter estimates. Best fitting models based on analyses summarized in Table II are presented

\begin{tabular}{ll}
\hline Species & \multicolumn{1}{c}{$R_{\mathrm{R}}$ equation } \\
\hline Micropogonias undulatus & $R_{\mathrm{R} 10 \mathrm{C}}=41 \cdot 3( \pm 7 \cdot 9) M^{0 \cdot 92( \pm 0 \cdot 14)}$ \\
& $R_{\mathrm{R} 15 \mathrm{C}}=38 \cdot 3( \pm 5 \cdot 6) M^{0 \cdot 65( \pm 0 \cdot 09)}$ \\
& $R_{\mathrm{R} 20 \mathrm{C}}=54 \cdot 8( \pm 9 \cdot 0) M^{0 \cdot 72( \pm 0 \cdot 15)}$ \\
& $R_{\mathrm{R} 25 \mathrm{C}}=85 \cdot 3( \pm 3 \cdot 6) M^{0.78( \pm 0 \cdot 04)}$ \\
Leiostomus xanthurus & $R_{\mathrm{R} 10 \mathrm{C}}=44 \cdot 5( \pm 23 \cdot 7) M^{0 \cdot 65( \pm 0 \cdot 22)}$ \\
& $R_{\mathrm{R} 15 \mathrm{C}}=28 \cdot 7( \pm 12 \cdot 9) M^{0 \cdot 44( \pm 0 \cdot 22)}$ \\
& $R_{\mathrm{R} 20 \mathrm{C}}=58 \cdot 5( \pm 8 \cdot 3) M^{0 \cdot 48( \pm 0 \cdot 06)}$ \\
Menticirrhus spp. & $R_{\mathrm{R} 25 \mathrm{C}}=64 \cdot 6( \pm 8 \cdot 3) M^{0.48( \pm 0.06)}$ \\
& $R_{\mathrm{Rall}}=149 \cdot 7( \pm 38 \cdot 5) M^{0.54( \pm 0 \cdot 18)}$ \\
\hline
\end{tabular}

species covariate (for $M$. saxatilis and M. americanus) did not improve fit relative to a model pooling both Menticirrhus species; both species were thus combined into a pooled model (Table III). At $25^{\circ} \mathrm{C}$, Menticirrhus spp. demonstrated an $R_{\mathrm{R}}$ roughly double that of $M$. undulatus and L. xanthurus and a shape parameter intermediate between the species (Table III).

For the analysis of sciaenid energy demand in the context of other fishes, the power model incorporating a covariate for energy demand (three levels) provided a superior

TABLE IV. Comparison of a power model fitted to pooled sciaenid energy demand data from this study and literature values $v$. a model parameterized to include a covariate for energy demand (three levels). For the pooled model, s.E. are presented for the estimates. For the Kimura model, values in the estimates column are presented as the difference from the reference group (R), and S.E. captures the precision of the change from the reference group for a given covariate level. $P$-values are associated with tests evaluating whether each parameter estimate is statistically different from zero. $\triangle \mathrm{AIC}$ was calculated by subtracting each model's AIC from the best fitting model's AIC ( $\triangle \mathrm{AIC}=0$ denotes best fit). Models with $\triangle \mathrm{AIC}<2$ have strong support, those with $\triangle \mathrm{AIC}>10$ have little to no support (Burnham \& Anderson, 2002). Bold AIC values indicate best fitting model

\begin{tabular}{lcccccc}
\hline Model & Parameter & Estimate \pm s.E. & $t$ & $P$ & AIC & $\Delta$ AIC \\
\hline All species & $a$ & $238.20 \pm 8.03$ & 29.66 & $<0.01$ & 2380.5 & 184.6 \\
pooled & $b$ & $0.88 \pm 0.03$ & 29.49 & $<0.01$ & & \\
Kimura, three groups & $\mathrm{A}_{\text {HED }}(\mathrm{R})$ & $345.70 \pm 7.93$ & 43.55 & $<0.01$ & $\mathbf{2 1 9 5 . 9}$ & $\mathbf{0}$ \\
& $\mathrm{A}_{\text {EED }}$ & $-153.40 \pm 30.22$ & -5.08 & $<0.01$ & & \\
& A $_{\text {SED }}$ & $-260.70 \pm 29.67$ & 8.79 & $<0.01$ & & \\
& B HED $_{\text {Hed }}$ & $0.54 \pm 0.02$ & 23.51 & $<0.01$ & & \\
& B $_{\text {EED }}$ & $0.18 \pm 0.18$ & 1.04 & $>0.05$ & & \\
& B $_{\text {SED }}$ & $0.19 \pm 0.25$ & 0.77 & $>0.05$ & & \\
\hline
\end{tabular}

EED, elevated-energy-demand species; HED, high-energy-demand species; SED, standard-energydemand teleosts. 


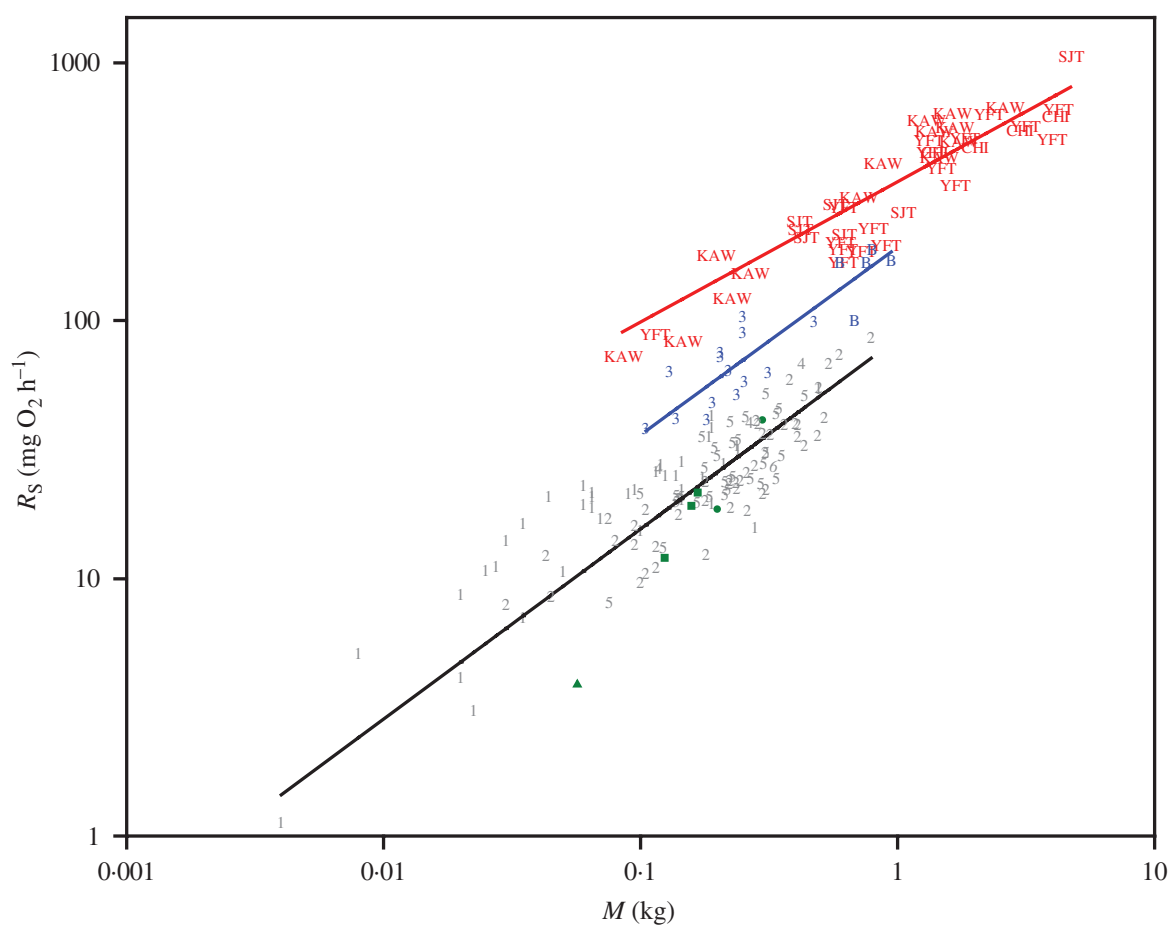

FIG. 3. Interspecific comparison of the relationship between resting metabolic rate $\left(R_{\mathrm{S}}\right)$ and mass $(M)$ of three groups of fishes categorized by energy demand: standard-energy-demand fishes $(-)\left(R_{\mathrm{S}}=85 \times M^{0.74}\right)$, elevated-energy-demand fishes $\left(\_\right)\left(R_{\mathrm{S}}=192 \times M^{0.72}\right)$ and high-energy-demand fishes $\left(\_\right)\left(R_{\mathrm{S}}=\right.$ $\left.345 \times M^{0.54}\right)$. All data were standardized to $25^{\circ} \mathrm{C}$ via a $Q_{10}$ of 1.65 (White et al., 2006). Standard energy demand teleosts include: 1, Leiostomus xanthurus; 2, Micropogonias undulatus; 4, Cynoscion regalis (A. Z. Horodysky, unpubl. data); 5, Cynoscion nebulosus (Vetter, 1982; A. Z. Horodysky, unpubl. data); 6, Argyrosomus japonicus (Fitzgibbon et al., 2007); [•], Oncorhynchus mykiss (Evans, 1990); [४], Salmo trutta (Sloman et al., 2000); [ ] , Gadus morhua (Schurmann \& Steffensen, 1997). Elevated energy demand teleosts include: 3, Menticirrhus spp. (this study) and B, Pomatomus saltatrix (P. G. Bushnell, unpubl. data). High energy demand teleosts include: SJT, Katsuwonus pelamis; YFT, Thunnus albacares; KAW, Euthynnus affinis and CHI, Coryphaena hippurus (Benetti et al., 1995; Brill, 1979; Dewar \& Graham, 1994; Sepulveda \& Dickson, 2000). Note that axes are log-transformed for graphical purposes, but data were not transformed for model fitting.

fit when compared to a model that pooled all species (see $\triangle \mathrm{AIC}$, Table IV). Leiostomus xanthurus and $M$. undulatus have $R_{\mathrm{R}}$ similar to a wide range of teleosts with fairly standard energy demands (Fig. 3). The metabolic rates of fishes with comparatively elevated energy demands including Menticirrhus spp. and bluefish Pomatomus saltatrix (L. 1766) were roughly double those of standard-energy-demand fishes. The metabolic rates of high-energy-demand species (Brill, 1996) such as tunas and the common dolphinfish Coryphaena hippurus L. 1758 were about nearly double those of elevated-demand-fishes and about four times higher than those of most teleosts. The estimated shape parameter $b$ was lowest in the high-demand fishes and roughly equivalent in elevated and standard-energy-demand teleosts.

Relative to standard non-linear regression, non-linear mixed-effects models fitted to the $M$. undulatus and L. xanthurus $R_{\mathrm{A}}$ data that accounted for repeated measures 
TABle V. Summary statistics for non-linear mixed-effects models fitted via maximum likelihood to (a) Micropogonias undulatus and (b) Leiostomus xanthurus active metabolic rate $\left(R_{\mathrm{A}}\right)$ data obtained at $25^{\circ} \mathrm{C}$. Models were of the form: $M_{\mathrm{O}_{2}}=a+b U^{c}$ (equation 3). Standard non-linear models did not account for any repeated measures or heteroscedasticity (NO). Repeated measures were considered only where indicated (RM), and covariance structures were default (D), autoregressive first-order [AR(1)], autoregressive moving average (ARMA) and compound symmetry (CS). For Akaike's information criterion (AIC) (equation 2) the lower value denotes better fit. $\triangle \mathrm{AIC}$ was calculated by subtracting each model's AIC from the best fitting model's AIC ( $\triangle \mathrm{AIC}=0$ denotes best fit). Models with $\triangle \mathrm{AIC}<2$ have strong support, those with $\triangle \mathrm{AIC}>10$ have little to no support (Burnham \& Anderson, 2002). The AIC values in bold indicate the model with best fit

\begin{tabular}{|c|c|c|c|c|c|}
\hline Model & $a \pm$ s.E. & $b \pm$ s.E. & $c \pm$ S.E. & AIC & $\Delta \mathrm{AIC}$ \\
\hline \multicolumn{6}{|l|}{ (a) } \\
\hline $\mathrm{NO}$ & $133 \cdot 1 \pm 43 \cdot 3$ & $88.7 \pm 28.0$ & $1.34 \pm 0.17$ & $1910 \cdot 0$ & $69 \cdot 3$ \\
\hline RM, D & $139.7 \pm 24.5$ & $82.1 \pm 17.6$ & $1.39 \pm 0.13$ & $1864 \cdot 2$ & $23 \cdot 5$ \\
\hline $\mathbf{R M}, \mathbf{A R}(1)$ & $126 \cdot 0 \pm 27 \cdot 2$ & $93.5 \pm 24.8$ & $1 \cdot 32 \pm 0 \cdot 16$ & 1841.5 & 0.8 \\
\hline RM, ARMA & $115 \cdot 3 \pm 28 \cdot 4$ & $106 \cdot 1 \pm 28 \cdot 0$ & $1.23 \pm 0.16$ & $1840 \cdot 7$ & $\mathbf{0}$ \\
\hline $\mathrm{RM}, \mathrm{CS}$ & $130 \cdot 8 \pm 24 \cdot 8$ & $88 \cdot 0 \pm 20 \cdot 6$ & $1.34 \pm 0.14$ & 1863.7 & 23 \\
\hline \multicolumn{6}{|l|}{ (b) } \\
\hline NO & $13 \cdot 0 \pm 116 \cdot 4$ & $246.4 \pm 95.4$ & $0.89 \pm 0.17$ & $2085 \cdot 3$ & 89.7 \\
\hline RM, D & $193 \cdot 1 \pm 23 \cdot 0$ & $69.8 \pm 15.6$ & $1 \cdot 60 \pm 0.12$ & $2005 \cdot 0$ & 9.4 \\
\hline $\mathbf{R M}, \mathbf{A R}(\mathbf{1})$ & $167 \cdot 2 \pm 41.2$ & $117 \cdot 1 \pm 40 \cdot 2$ & $1 \cdot 26 \pm 0.16$ & $1995 \cdot 8$ & 0.2 \\
\hline RM, ARMA & $176 \cdot 6 \pm 37 \cdot 8$ & $108 \cdot 0 \pm 36.5$ & $1 \cdot 31 \pm 0.18$ & 1995.6 & $\mathbf{0}$ \\
\hline $\mathrm{RM}, \mathrm{CS}$ & $193 \cdot 0 \pm 22 \cdot 1$ & $67 \cdot 6 \pm 15.5$ & $1.66 \pm 0.12$ & $2007 \cdot 4$ & $11 \cdot 8$ \\
\hline
\end{tabular}

(by specifying the within-individual covariance) and adjusted for heteroscedasticity improved model fit, satisfied normality of the residual error and reduced s.E. of parameter estimates including the $y$-intercept (Table V and Fig. 4). Specifically, autoregressive first-order [AR(1)] and autoregressive moving average (ARMA) covariance models significantly outfit all other models considered for both $L$. xanthurus and M. undulatus. ARMA models slightly outfit AR(1) models (Table V); estimates from the former were therefore used in subsequent calculations. For both species, ARMA model $y$-intercepts fit neatly within the $95 \%$ C.I. of the $R_{\mathrm{R}}$ at $25^{\circ} \mathrm{C}$, calculated for each species by substituting the mean mass of individuals used in the swim trials into equation 1 . The maximum $R_{\mathrm{A}}$ were $869.2 \mathrm{mg} \mathrm{O}_{2} \mathrm{~kg}^{-1} \mathrm{~h}^{-1}$ for $M$. undulatus and $1274.9 \mathrm{mg} \mathrm{O}_{2} \mathrm{~kg}^{-1} \mathrm{~h}^{-1}$ for L. xanthurus, which suggest factorial metabolic scopes $\left(R_{\mathrm{A}} R_{\mathrm{R}}^{-1}\right)$ of 7.2 and 10.6 times $R_{\mathrm{S}}$, respectively (Table VI). It should be noted, however, that $M$. undulatus in this study were roughly $1.5-2$ times greater in $M$ than L. xanthurus.

The $C_{\mathrm{G}}$ and $C_{\mathrm{N}}$ were calculated from the M. undulatus and L. xanthurus $R_{\mathrm{A}}$ data and equation 3 parameters resulting from ARMA models (Table VI). For both species, $C_{\mathrm{G}}$ assumed a J-shaped curve with initial high costs and subsequently reduced costs at intermediate swimming speeds (Fig. 5). The optimal swimming speeds $\left(U_{\mathrm{opt}}\right)$, calculated from equation 6 , were $3.5 \mathrm{BL} \mathrm{s}^{-1}$ for M. undulatus and $3.6 \mathrm{BL} \mathrm{s}^{-1}$ for L. xanthurus. The $C_{\mathrm{Nmin}}$ were $0.54 \mathrm{~J} \mathrm{~kg}^{-1} \mathrm{BL}^{-1}$ for $M$. undulatus and L. xanthurus, while the $C_{\mathrm{Gmin}}$ were 0.66 and $0.79 \mathrm{~J} \mathrm{~kg}^{-1} \mathrm{BL}^{-1}$, respectively. 

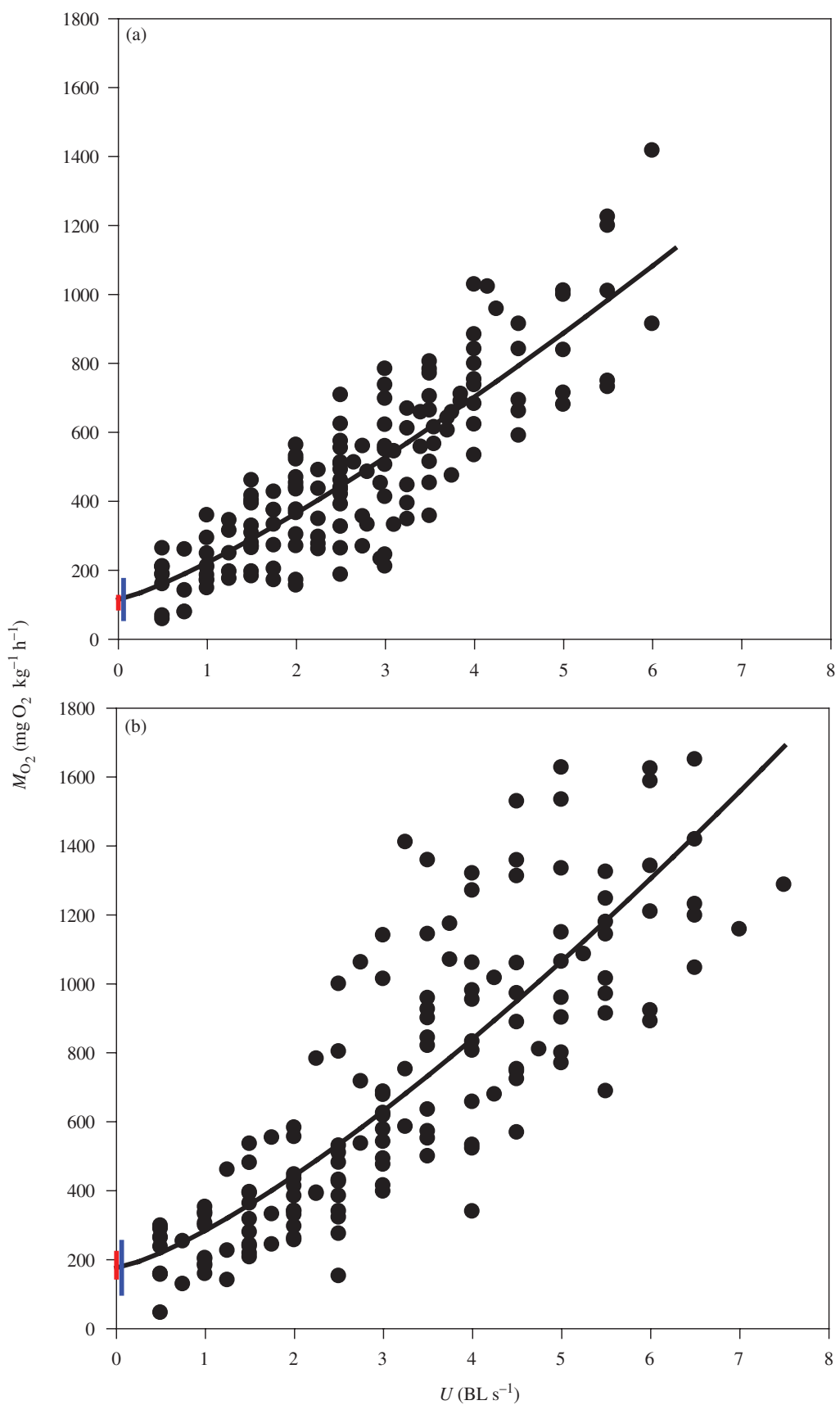

FIG. 4. Oxygen consumption $\left(M_{\mathrm{O}_{2}}\right)$ as a function of swimming speed $(U)$ of (a) Micropogonias undulatus ( $n=15$ ) and (b) Leiostomus xanthurus $(n=12)$ at $25^{\circ} \mathrm{C}$. The curve represents the best fitting equation (equation 3). For both species, repeated-measures linear mixed-effects models using the ARMA covariance matrix best fit the active metabolic rate $\left(R_{\mathrm{A}}\right)$ data; corresponding parameter estimates and AIC model fits are given in Table V. Red lines denote 95\% C.I. of resting metabolic rate $\left(R_{\mathrm{R}}\right)$ for a fish with mean mass $(M)$ of all swum individuals (equation 1) and blue lines denote $95 \%$ C.I. of $y$-intercept estimated by the best fitting ARMA model (equation 3) for each species (Table V). 
TABLE VI. Summary of the estimated standard metabolic rate $\left(R_{\mathrm{S}}\right) \pm$ S.E., mean resting metabolic rates $\left(R_{\mathrm{R}}\right)$, maximum active metabolic rate $\left(R_{\mathrm{A}}\right)$, metabolic scope, optimum swimming speeds $\left(U_{\text {opt }}\right)$, minimum net costs of transport $\left(C_{\mathrm{Nmin}}\right)$ and minimum gross costs of transport $\left(C_{\mathrm{Gmin}}\right)$ for Micropogonias undulatus and Leiostomus xanthurus at $25^{\circ} \mathrm{C}$. Micropogonias undulatus in this study were roughly $1.5-2$ times greater in mass $(M)$ than $L$. xanthurus (Table I). The $R_{\mathrm{S}}$ values were estimated by obtaining the $y$-intercept ( $0 \mathrm{BL}$ $\mathrm{s}^{-1}$ ) of the best fitting $R_{\mathrm{A}}$ power function (equation 3), while mean $R_{\mathrm{R}}$ was calculated by inserting the mean $R_{\mathrm{A}}$ experimental subject $M$ into the appropriate $25^{\circ} \mathrm{C}$ equations from Tables II and III. Metabolic scope was calculated as maximum $R_{\mathrm{A}} R_{\mathrm{R}}^{-1}$

\begin{tabular}{llc}
\hline Parameter & M. undulatus & L. xanthurus \\
\hline$R_{\mathrm{S} 25 \mathrm{C}}$ estimate $\left(\mathrm{mg} \mathrm{O}_{2} \mathrm{~kg}^{-1} \mathrm{~h}^{-1}\right)$ & $115 \cdot 3 \pm 28 \cdot 4$ & $176 \cdot 6 \pm 37 \cdot 8$ \\
Mean $R_{\mathrm{R} 25 \mathrm{C}}\left(\mathrm{mg} \mathrm{O}_{2} \mathrm{~kg}^{-1} \mathrm{~h}^{-1}\right)$ & $113 \cdot 3 \pm 8 \cdot 2$ & $194 \cdot 1 \pm 17 \cdot 9$ \\
Maximum $R_{\mathrm{A}}\left(\mathrm{mg} \mathrm{O}_{2} \mathrm{~kg}^{-1} \mathrm{~h}^{-1}\right)$ & $869 \cdot 2 \pm 71 \cdot 7$ & $1274.9 \pm 55 \cdot 3$ \\
Scope $\left(\mathrm{mg} \mathrm{O}_{2} \mathrm{~kg}^{-1} \mathrm{~h}^{-1}\right)$ & $7 \cdot 5$ & $7 \cdot 2$ \\
$U_{\text {opt }}\left(\mathrm{BL} \mathrm{s}^{-1}\right)$ & $3 \cdot 5$ & $3 \cdot 6$ \\
$C_{\mathrm{Nmin}}\left(\mathrm{J} \mathrm{kg}^{-1} \mathrm{BL}^{-1}\right)$ & $0 \cdot 54$ & 0.54 \\
$C_{\mathrm{Gmin}}\left(\mathrm{J} \mathrm{kg}^{-1} \mathrm{BL}^{-1}\right)$ & $0 \cdot 66$ & $0 \cdot 79$ \\
\hline
\end{tabular}

\section{DISCUSSION}

\section{RESTING METABOLISM}

The superior fit of models containing a covariate for temperature relative to models that pooled across temperature demonstrate that the $R_{\mathrm{R}}$ of $M$. undulatus and L. xanthurus increase with $M$ and temperature, as do those of a wide variety of species. By definition, $R_{\mathrm{R}}$ measurements overestimate $R_{\mathrm{S}}$ due to the spontaneous
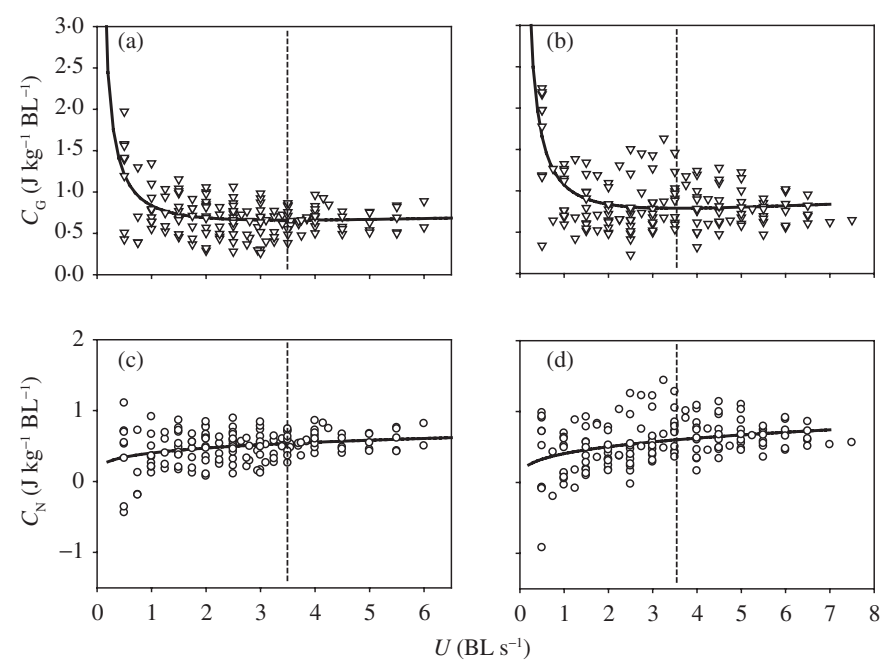

FIG. 5. The (a), (b) gross costs of transport $\left(C_{\mathrm{G}}\right)$ and (c), (d) net costs of transport $\left(C_{\mathrm{N}}\right)$ for (a), (c) Micropogonias undulatus $(n=15)$ and $(\mathrm{b})$, (d) Leiostomus xanthurus $(n=12)$ swum $(U)$ at $25^{\circ} \mathrm{C}$. Note different $x$-axis scale for L. xanthurus. _ _ predicted values calculated from parameter estimates from equations 4 and 5. :, $C_{\mathrm{Gmin}}$ and $C_{\mathrm{Nmin}}$ at the $U_{\mathrm{opt}}$ of each species, calculated from equation 6 . 
movements of subjects to maintain position and posture. Nonetheless, these results agree with previous investigations of $R_{\mathrm{R}}$ in larvae and juveniles of both species (Hoss et al., 1988; Moser \& Hettler, 1989). Interspecific comparisons to a wide array of taxa suggest that $M$. undulatus and $L$. xanthurus have $R_{\mathrm{R}}$ that are very typical for most freshwater, anadromous and marine teleosts (Fig 3). When compared to other taxa, the $R_{\mathrm{R}}$ of $M$. undulatus and $L$. xanthurus align with the $R_{\mathrm{R}}$ of rainbow trout Oncorhynchus mykiss (Walbaum 1792), brown trout Salmo trutta L.1758 and Atlantic cod Gadus morhua L.1758, as well as several other sciaenid species including weakfish Cynoscion regalis (Bloch \& Schneider 1801) (A. Z. Horodysky, unpubl. data), silver seatrout Cynoscion arenarius Ginsburg 1930, spotted seatrout Cynoscion nebulosus (Cuvier 1830) (Vetter, 1982) and mulloway Argyrosomus japonicus (Temminck \& Schlegel 1843) (Fitzgibbon et al., 2007). At $25^{\circ} \mathrm{C}$, the metabolic rates of most teleosts were roughly a quarter of those observed in high-energy-demand species such as Thunnus spp. and C. hippurus (Brill, 1996).

An unexpected finding in this study was that the energy demand of Menticirrhus spp. roughly doubles that of most fishes with standard energy demands (including M. undulatus and L. xanthurus) and is c. 1.8 times lower than the high-energydemand fishes (i.e. Thunnus spp.) (Table IV). The $R_{\mathrm{R}}$ of Menticirrhus spp. were similar to those of P. saltatrix (P. G. Bushnell, unpubl. data; Fig 3.), a highly active, fast-growing coastal pelagic species. Menticirrhus spp., L. xanthurus and M. undulatus have been grouped by some authors on the basis of life-history strategies (longevity and maximum body size, and rapid maturity) that are intermediate relative to other sciaenids (Waggy et al., 2006), but interesting differences in habitat use and morphology exist among the species. Menticirrhus spp. almost exclusively use median and paired fin gaits in captivity (A. Z. Horodysky, pers. obs.), which may provide enhanced mobility in the high wave-energy and oxygen-saturated littoral zones that the species frequents. By contrast, M. undulatus and L. xanthurus display an array of fin propulsion mechanisms and inhabit a myriad of aquatic habitats (Chao \& Musick, 1977). It is likely that the elevated growth rate of Menticirrhus spp. (Miller et al., 2002) is linked to their substantially elevated $R_{\mathrm{R}}$ relative to other sciaenids. It has been postulated that high maximum $R_{\mathrm{A}}$ allow high growth rates (Brill, 1996), which are supported by higher rates of oxygen extraction and delivery made possible by larger gill surface areas (Pauly, 1981) which in turn appear linked to elevated $R_{\mathrm{S}}$ (Brill, 1987, 1996; Boggs \& Kitchell, 1991). While gill surface areas have not been examined in sciaenids, Menticirrhus spp. demonstrate substantially higher heart rates than either M. undulatus or L. xanthurus (R. W. Brill and P. G. Bushnell, upubl. data), suggesting high oxygen and metabolite distribution capabilities that could support the elevated energy demands and $R$. The physiological mechanisms and ecological consequences of elevated $R_{\mathrm{R}}$ in Menticirrhus spp. remain unclear, and further study within the genus is clearly warranted.

\section{ACTIVE METABOLISM}

The $R_{\mathrm{A}}$ and $C$ in fishes are typically determined by measuring $M_{\mathrm{O}_{2}}$ of individuals at increasing $U$, yet few studies have accounted for the within-individual autocorrelation or heteroscedastic variance that generally results from such experiments. Failure to consider these fundamental violations of regression assumptions can result in biased or invalid parameter estimates, s.E. and metrics of fit as well as inflated 
probability of type I errors (falsely concluding significance; Underwood, 2002). Individually fitting power functions to each fish and averaging parameter estimates would suffer from autocorrelated within-individual errors.

The consideration of whether to treat fishes as a fixed or random effect in modelling procedures strongly affects the resulting scope of inference. Considering 'fish' as a fixed effect (i.e. not specifying it as a random effect in the model) limits inference to specific experimental subjects and does allow inferences to be applied to the population from which samples were obtained (Davidian \& Giltinan, 1995). By contrast, mixed-effects models account for variability in the global population and increase the scope of inference to the larger wild population from which subjects were sampled by treating subjects as truly random samples of the larger population (Littell et al., 2006).

In this study, repeated-measures non-linear mixed-effects models with AR(1) and ARMA covariance structures that accounted for heteroscedacity applied to the $M$. undulatus and $L$. xanthurus $R_{\mathrm{A}}$ data significantly improved model fits and reduced parameter S.E. relative to standard non-linear regression. Both AR(1) and ARMA covariance structures assume that the correlation between observations is a function of their lag in time; adjacent observations (in this case, $M_{\mathrm{O}_{2}}$ at adjoining $U$ ) are more likely to be strongly correlated than those taken further apart (i.e. at dissimilar $U$ ) within an individual (Pinheiro \& Bates, 2004). ARMA models include an additional moving average smoothing parameter and may outperform $\mathrm{AR}(1)$ models when data are particularly noisy (Pinheiro \& Bates, 2004), such as in $R_{\mathrm{A}}$ experiments with wild fishes that may vary in body condition and size. Information Theoretic model selection via AIC provides an objective balance between model simplicity (fewer parameters) and fit; models are penalized for additional parameters (Burnham \& Anderson, 2002). Collectively, these methods hold great potential for improving the analyses of data resulting from $R_{\mathrm{A}}$ and other repeated-measures metabolic experiments.

The $R_{\mathrm{R}}$ and $R_{\mathrm{S}}$ converge when within-chamber activity is low. Regressing ARMA power performance curves to zero $U$ (i.e. $y$-intercept) generated estimates of $R_{\mathrm{S}}$ that neatly aligned within the $95 \%$ C.I. of experimental measurements of $R_{\mathrm{R}}$ for $M$. undulatus and L. xanthurus (Table VI and Fig. 4). The lack of significant differences in these two complementary techniques demonstrates that the $R_{\mathrm{S}}$ estimated in this study are probably close to true $R_{\mathrm{S}}$ and confirm the validity of the approach and the utility of repeated-measures methods for $R_{\mathrm{S}}$ estimation from $R_{\mathrm{A}}$ experiments. Potential increases in $M_{\mathrm{O}_{2}}$ above values expected at low swimming speeds due to stress and spontaneous activity (Bushnell et al., 1984), however, may still hamper the estimation of $R_{\mathrm{S}}$ from $R_{\mathrm{A}}$ experiments using these and other analytical methods.

Swimming respirometry revealed that L. xanthurus had higher maximum $R_{\mathrm{A}}$ and broader metabolic scopes than M. undulatus. It should be noted, however, that $M$. undulatus in this study were roughly 1.5-2 times greater in $M$ than L. xanthurus, thus some of this effect may be due to differences in $M$. The maximum $R_{\mathrm{A}}$ of $M$. undulatus and L. xanthurus were 2.3 and 3.5 times higher than those of cultured A. japonicus, a Pacific sciaenid (Fitzgibbon et al., 2007), comparable to those of sockeye salmon Oncorhynchus nerka (Walbaum 1792) corrected to $25^{\circ}$ (Brett, 1965), but less than half of the $R_{\mathrm{A}}$ of yellowfin tuna Thunnus albacares Bonnaterre 1788 (Korsmeyer et al., 1996). Factorial scopes of M. undulatus (7.5) and L. xanthurus (7-2) were within the range for O. nerka (4-16; Brett, 1965), similar to those observed in T. albacares (11.5; Korsmeyer et al., 1996), and higher than those 
observed in Atlantic cod Gadus morhua L. 1758 (3.1; Schurmann \& Steffensen, 1997), O. mykiss (3.9; Bushnell et al., 1984), Pacific yellowtail Seriola lalandi Valenciennes 1833 (4.0; Clark \& Seymour, 2006) and A. japonicus (5; Fitzgibbon et al., 2007). These results suggest that the metabolic scopes of M. undulatus and L. xanthurus are typical for standard-energy-demand fishes of similar morphologies and life styles. Finally, $U_{\mathrm{opt}}$ values for M. undulatus $\left(3.5 \mathrm{BL} \mathrm{s}^{-1}\right)$ and $L$. xanthurus (3.6 $\mathrm{BL} \mathrm{s}^{-1}$ ) were higher than those of several sciaenids including red drum Sciaenops ocellatus (L. 1766) (3.0 BL s $\left.{ }^{-1}\right)$, C. nebulosus $\left(2.7 \mathrm{BL} \mathrm{s}^{-1}\right.$ ) and A. japonicus (1.3 $\mathrm{BL} \mathrm{s}^{-1}$ ) (Videler, 1993; Fitzgibbon et al., 2007). Additionally, $U_{\text {opt }}$ probably approximates routine swimming velocity in highly migratory fishes, but the routine swimming velocities of more sedentary species are probably much less than $U_{\text {opt }}$ (Videler, 1993; Steinhausen et al., 2005). Interspecific comparisons of $U_{\text {opt }}$ are, however, complicated by the use of numerous testing protocols ( $U$ increments and durations), study temperatures, individual status (wild $v$. culture), body conditions and sizes and variable life histories (Fitzgibbon et al., 2007).

The $R_{\mathrm{A}}$ in fishes range widely due to diverse biochemical, morphological and physiological adaptations among taxa, allowing insights into the bounds of energy requirements and $C$. The $C_{\mathrm{G}}$ is a measure of the energy required to travel a unit difference and frequently assumes a J-shaped function with high initial $C$ when $R_{\mathrm{S}}$ dominates total $M_{\mathrm{O}_{2}}$, low intermediate $C$ and increasing values above $U_{\text {opt }}$ due to steeply increasing hydrodynamic resistance with $U$. The $C_{\mathrm{N}}$ is a measure of the $C$ excluding $R_{\mathrm{S}}$; the proportional contribution of $C_{\mathrm{N}}$ to $C_{\mathrm{G}}$ thus increases with increasing $U$. The $C_{\mathrm{G}}$ and $C_{\mathrm{N}}$ of $M$. undulatus and L. xanthurus are classic examples of this pattern, although increases above $U_{\text {opt }}$ are slight (Fig. 5). The $C_{\mathrm{G}}$ for L. xanthurus and $M$. undulatus appear only marginally affected over a broad range of intermediate and higher $U$ (fairly unsubstantial $C$ increases with $U$ ), typical of low-drag swimming and foraging generalist fishes that have adapted for swimming performance at higher $U$ (Pettersson \& Hedenström, 2000). Juvenile M. undulatus and L. xanthurus may not move great distances within estuarine nursery habitats at $25^{\circ} \mathrm{C}$; however, adults of these and many other fishes undertake pronounced offshore migrations when inshore and estuarine temperatures decline to $10-15^{\circ} \mathrm{C}$ (Murdy et al., 1997). Future $R_{\mathrm{A}}$ experiments conducted at 10 and $15^{\circ} \mathrm{C}$ will permit the estimation of the energetic costs of these winter migrations.

The authors thank S. Wray, J. Lucy, J. Smith, P. Lynch and R.V. Bada Bing and Sea Beaver for their assistance in collecting study animals, and M. Luckenbach, R. Bonniwell and S. Fate provided logistical assistance and extreme flexibility in support of these experiments. Assistance with animal husbandry was graciously provided by C. Magel, L. Pace and C. Speaks; R. Seifert and T. Nania assisted with husbandry and swim experiments. Comments on a previous draft were provided by J. F. Steffensen. The authors thank the two anonymous reviewers for their thorough efforts in improving this manuscript. Partial support for this research was provided by the National Marine Fisheries Service and by an award to A.Z.H. from the International Women's Fishing Association. This is Virginia Institute of Marine Science contribution \#3157.

\section{References}

Akaike, H. (1973). Information theory as an extension of the maximum likelihood principle. In Second International Symposium on Information Theory (Petrov, B. N. \& Csaki, F., eds), pp. 267-281. Budapest: Akademiai Kiado. 
Alsop, D. \& Wood, C. (1997). The interactive effects of feeding and exercise on oxygen consumption, swimming performance and protein usage in juvenile rainbow trout (Oncorhynchus mykiss). Journal of Experimental Biology 200, 2337-2346.

Barton, B. A. \& Schreck, C. B. (1987). Metabolic cost of acute physical stress in juvenile steelhead. Transactions of the American Fisheries Society 166, 257-263.

Beamish, F. W. H. (1964). Respiration of fishes with special emphasis on standard oxygen consumption. II. Influence of weight and temperature on respiration of several species. Canadian Journal of Zoology 42, 77-188.

Beamish, F. W. H. (1974). Apparent specific dynamic action of largemouth bass, Micropterus salmoides. Journal of the Fisheries Research Board of Canada 31, 1763-1769.

Benetti, D. D., Brill, R. W. \& Kraul, S. A. (1995). The standard metabolic rate of dolphin fish. Journal of Fish Biology 46, 987-996. doi: 10.1111/j.1095-8649.1995.tb01403.x

Blažka, P., Volf, M. \& Cepela, M. (1960). A new type of respirometer for the determination of the metabolism of fish in an active state. Physiologia Bohemoslovenica 9, 553-558.

Boef, G. \& Le Bail, P-Y. (1999). Does light have an influence on fish growth? Aquaculture 177, 129-152.

Boggs, C. H. \& Kitchell, J. F. (1991). Tuna metabolic rates estimated from energy losses during starvation. Physiological Zoology 64, 502-524.

Boisclair, D. \& Sirois, P. (1993). Testing assumptions of fish bioenergetics models by direct estimation of growth, consumption, and activity rates. Transactions of the American Fisheries Society 122, 784-796.

Boisclair, D. \& Tang, M. (1993). Empirical analysis of the influence of swimming pattern on the net energetic cost of swimming in fishes. Journal of Fish Biology 42, 169-183. doi: 10.1111/j.1095-8649.1993.tb00319.x

Brandt, S. B. \& Hartman, K. J. (1993). Innovative approaches with bioenergetics models: future applications to fish ecology and management. Transactions of the American Fisheries Society 122, 731-735.

Breitburg, D. (2002). Effects of hypoxia, and the balance between hypoxia and enrichment, on coastal fishes and fisheries. Estuaries 25, 767-781.

Brett, J. R. (1964). The respiratory metabolism and swimming performance of young sockeye salmon. Journal of the Fisheries Research Board Canada 21, 1183-1226.

Brett, J. R. (1965). The relation of size to rate of oxygen consumption and sustained swimming speed of sockeye salmon (Oncorhynchus nerka). Journal of the Fisheries Research Board of Canada 22, 1491-1501.

Brett, J. R. \& Groves, T. D. D. (1979). Physiological energetics. In Fish Physiology, Vol. 8 (Hoar, W. S., Randall, D. J. \& Brett, J. R., eds), pp. 279-352. New York, NY: Academic Press.

Brill, R. W. (1979). The effect of body size on the standard metabolic rate of skipjack tuna, Katsuwonus pelamis. Fisheries Bulletin (U.S.) 77, 494-498.

Brill, R. W. (1987). On the standard metabolic rates of tropical tunas, including the effects of body size and acute temperature change. Fisheries Bulletin (U.S.) 85, 25-35.

Brill, R. W. (1996). Selective advantages conferred by the high performance physiology of tunas, billfishes, and dolphin fish. Comparative Physiology and Biochemistry A 113, $3-15$.

Brougher, D. S., Douglass, L. W. \& Soares, J. H. (2005). Comparative oxygen consumption and metabolism of striped bass Morone saxatilis and its hybrid M. chrysops $\times M$. saxatilis. Journal of the World Aquaculture Society 36, 521-529. doi: 10.1111/j.17497345.2005.tb00400.x

Burke, B. J. \& Rice, J. A. (2002). A linked foraging and bioenergetics model for southern flounder. Transactions of the American Fisheries Society 131, 120-131.

Burnham, K. P. \& Anderson, D. R. (2002). Model Selection and Multimodel Inference: A Practical Information-Theoretic Approach, 2nd edn. New York, NY: Springer Science and Business Media.

Bushnell, P. G., Steffensen, J. F. \& Johansen, J. (1984). Oxygen consumption and swimming performance in hypoxia-acclimated rainbow trout Salmo gairdneri. Journal of Experimental Biology 113, 225-235. 
Chao, L. N. \& Musick, J. A. (1977). Life history, feeding habits, and functional morphology of juvenile sciaenid fishes in the York River estuary, Virginia. Fishery Bulletin 75, $657-702$.

Chapman, L. J., Kaufman, L. S., Chapman, C. A. \& McKenzie, F. E. (1995). Hypoxia tolerance in twelve species of east African cichlids: potential for low oxygen refugia in Lake Victoria. Conservation Biology 9, 1274-1287. doi: 10.1046/j.1523-1739.1995.90512 62.x-i1

Chapman, L. J., Chapman, C. A., Nordlie, F. G. \& Rosenberger, A. E. (2002). Physiological refugia: swamps, hypoxia tolerance, and maintenance of fish diversity in the Lake Victoria region. Comparative Biochemistry and Physiology A 133, 421-437.

Claireaux, G., Couturier, C. \& Groison, A-L. (2006). Effect of temperature on maximum swimming speed and cost of transport in juvenile European sea bass (Dicentrarchus labrax). Journal of Experimental Biology 209, 3420-3428.

Clark, T. D. \& Seymour, R. S. (2006). Cardiorespiratory physiology and swimming energetics of a high-energy-demand teleost, the yellowtail kingfish (Seriola lalandi). Journal of Experimental Biology 209, 3940-3951. doi: 10.1242/jeb.02440

Clarke, A. \& Johnston, A. M. (1999). Scaling of metabolic rate with body mass and temperature in teleost fish. Journal of Animal Ecology 68, 893-905. doi: 10.1046/j.13652656.1999.00337.x

Davidian, M. \& Giltinan, D. M. (1995). Nonlinear Models for Repeated Measurement Data. London: Chapman \& Hall.

Dejours, P. (1975). Principles of Comparative Respiratory Physiology. New York, NY: Elsevier.

Dewar, H. \& Graham, J. B. (1994). Studies of tropical tuna swimming performance in a large water tunnel. I. Energetics. Journal of Experimental Biology 192, 12-31.

van Dijk, P. L. M., Tesch, C., Hardewig, I. \& Pörtner, H. O. (1999). Physiological disturbances at critically high temperatures: a comparison between stenothermal Antarctic and eurythermal temperate eelpouts (Zoarcidae). Journal of Experimental Biology 202, $3611-3621$.

Dowd, W. W., Brill, R. W., Bushnell, P. G. \& Musick, J. A. (2006). Standard and routine metabolic rates of juvenile sandbar sharks (Carcharhinus plumbeus), including effects of body mass and acute temperature change. Fishery Bulletin (U.S.) 104, 323-331.

Elliott, J. M. \& Davison, W. (1975). Energy equivalents of oxygen consumption in animal energetics. Oecologia 19, 195-201.

Evans, D. O. (1990). Metabolic thermal compensation by rainbow trout: effects on standard metabolic rate and potential usable power. Transactions of the American Fisheries Society 119, 585-600.

Ferry-Graham, L. A. \& Gibb, A. C. (2001). Comparison of fasting and postfeeding metabolic rates in a sedentary shark, Cephaloscyllium ventriosum. Copeia 2001, 1108-1113.

Fitzgibbon, Q. P., Strawbridge, A. \& Seymour, R. S. (2007). Metabolic scope, swimming performance, and the effects of hypoxia in the mulloway, Argyrosomus japonicus (Pisces: Sciaenidae). Aquaculture 270, 358-368.

Fry, F. E. J. (1947). Effects of the environment on animal activity. Publications of the Ontario Fisheries Research Laboratory 68, 1-62.

Hartman, K. J. \& Brandt, S. B. (1995). Comparative energetics and the development of bioenergetics models for sympatric estuarine piscivores. Canadian Journal of Fisheries and Aquatic Sciences 52, 1647-1666. doi: 10.1139/f95-759

Hettler, W. F. (1976). Influence of temperature and salinity on routine metabolic rate and growth of young Atlantic menhaden. Journal of Fish Biology 8, 55-65.doi: 10.1111/ j.1095-8649.1976.tb03907.x

Hewett, S. W. \& Kraft, C. E. (1993). The relationship between growth and consumption: comparisons across fish populations. Transactions of the American Fisheries Society 122, 814-821.

Hölker, F. (2003). The metabolic rate of roach in relation to body size and temperature. Journal of Fish Biology 62, 565-579. doi: 10.1046/j. 1095-8649.2003.00048.x

Horodysky, A. Z., Brill, R. W., Fine, M. L., Musick, J. A. \& Latour, R. J. (2008a). Acoustic pressure and particle motion thresholds in six sciaenid fishes. Journal of Experimental Biology 211, 1504-1511. doi: 10.1242/jeb.016196 
Horodysky, A. Z., Brill, R. W., Warrant, E. J., Musick, J. A. \& Latour, R. J. (2008b). Comparative visual function in five sciaenid fishes inhabiting Chesapeake Bay. Journal of Experimental Biology 211, 3601-3612. doi: 10.1242/jeb.023358

Hoss, D. E., Coston-Clements, L., Peters, D. S. \& Tester, P. A. (1988). Metabolic responses of spot, Leiostomus xanthurus, and Atlantic croaker, Micropogonias undulatus, larvae to cold temperatures encountered following recruitment to estuaries. Fishery Bulletin 86, $483-488$.

Hurlbert, S. H. (1984). Pseudoreplication and the design of ecological field experiments. Ecological Monographs 54, 187-211.

Jobling, M. (1994). Fish Bioenergetics. New York, NY: Chapman \& Hall.

Jonassen, T. M., Imsland, A. K., Kadowaki, S. \& Stefansson, S. O. (2000). Interaction of temperature and photoperiod on growth of Atlantic halibut Hippoglossus hippoglossus L. Aquaculture Research 31, 219-227.

Kimura, D. K. (2008). Extending the von Bertalanffy growth model using explanatory variables. Canadian Journal of Fisheries and Aquatic Sciences 65, 1879-1891.

Kitchell, J. F., Stewart, D. J. \& Weininger, D. (1977). Applications of a bioenergetics model to perch (Perca flavescens) and walleye (Stizostedion vitreum). Journal of the Fisheries Research Board of Canada 34, 1922-1935.

Korsmeyer, K. E., Dewar, H., Lai, N. C. \& Graham, J. B. (1996). The aerobic capacity of tunas: adaptation for multiple metabolic demands. Comparative Biochemistry and Physiology A 113, 17-24.

Krogh, A. (1914). The quantitative relation between temperature and standard metabolism in animals. Internationale Zeitschrift für Physikalisch-Chemische Biologie, 1, 491-508.

Littell, R. C., Milliken, G. A., Stroup, W. W., Wolfinger, R. D. \& Schabenberger, O. (2006). SAS for Mixed Models, 2nd edn. Cary, NC: SAS Institute.

MacIsaac, P. F., Goff, G. P. \& Speare, D. J. (1997). Comparison of routine oxygen consumption rates of three pleuronectids at three temperatures. Journal of Applied Ichthyology 13, 171-176. doi: 10.1111/j.1439-0426.1997.tb00117.x

McCarthy, I. D. (2001). Competitive ability is related to metabolic asymmetry in juvenile rainbow trout. Journal of Fish Biology 59, 1002-1014. doi: 10.1111/j.1095-8649.2001. tb00167.x

Metcalfe, N. B., Taylor, A. C. \& Thorpe, J. E. (1995). Metabolic rate, social status and lifehistory strategies in Atlantic salmon. Animal Behavior 49, 431-436.

Miller, M. J., Rowe, P. M. \& Able, K. W. (2002). Occurrence and growth rates of youngof-year northern kingfish, Menticirrhus saxatilis, on ocean and estuarine beaches in southern New Jersey. Copeia 2002, 815-823.

Morris, D. J. \& North, A. W. (1984). Oxygen consumption of five species of fish from south Georgia. Journal of Experimental Marine Biology and Ecology 78, 75-86.

Moser, M. L. \& Hettler, W. F. (1989). Routine metabolism of juvenile spot, Leiostomus xanthurus (Lacépède), as a function of temperature, salinity, and weight. Journal of Fish Biology 35, 703-707. doi: 10.1111/j.1095-8649.1989.tb03021.x

Muir, B. S., Nelson, G. J. \& Bridge, K. W. (1965). A method for measuring swimming speed in oxygen consumption studies on the aholehole Kuhlia sandvicensis. Transactions of the American Fisheries Society 94, 378-382.

Murdy, E. O., Birdsong, R. S. \& Musick, J. A. (1997). Fishes of Chesapeake Bay. Washington, DC: Smithsonian Institution Press.

Myers, G. S. (1960). Restriction of the croakers (Sciaenidae) and anchovies (Engraulidae) to continental waters. Copeia 1960, 67-68.

Ney, J. J. (1993). Bioenergetics modeling today: growing pains on the cutting edge. Transactions of the American Fisheries Society 122, 736-748.

Oikawa, S., Itazawa, Y. \& Gotoh, M. (1991). Ontogenetic change in the relationship between metabolic rate and body mass in a sea bream Pagrus major (Temminck \& Schlegel). Journal of Fish Biology 38, 483-496. doi: 10.1111/j.1095-8649.1991.tb03136.x

Pauly, D. (1981). The relationships between gill surface area and growth performance in fish: a generalization of von Bertalanffy's theory of growth. Berichte der Deutschen Wissenchaftlichen Kommission für Meeresforschung 28, 251-282.

Pettersson, L. B. \& Hedenström, A. (2000). Energetics, cost reduction and functional consequences of fish morphology. Proceedings of the Royal Society B 267, 759-764. 
Pichavant, K., Person-Le-Ruyet, J., Le Bayon, N., Severe, A., Le Roux, A. \& Bouef, G. (2001). Comparative effects of long term hypoxia on growth, feeding, and oxygen consumption in juvenile turbot and European sea bass. Journal of Fish Biology 59, 875-883. doi: 10.1111/j.1095-8649.2001.tb00158.x

Pinheiro, J. C. \& Bates, D. M. (2004). Mixed Effects Models in S and S-PLUS. New York, NY: Springer.

Post, J. R. \& Lee, J. A. (1996). Metabolic ontogeny of teleost fishes. Canadian Journal of Fisheries and Aquatic Sciences 53, 910-923.

Prosser, C. L. (1973). Temperature. In Comparative Animal Physiology, (Prosser, C. L., ed.), pp. 362-428. Philadelphia, PA: W.B. Saunders.

Richards, F. A. (1965). Dissolved gases other than carbon dioxide. In Chemical Oceanography (Riley, J. P. \& Skirrow, G., eds), pp. 197-224. New York, NY: Academic Press.

Schurmann, H. \& Steffensen, J. F. (1997). Effects of temperature, hypoxia, and activity on the metabolism of juvenile Atlantic cod. Journal of Fish Biology 50, 1166-1180. doi:10.1111/j.1095-8649.1997.tb01645.x

Secor, S. M. (2009). Specific dynamic action: a review of the postprandial metabolic response. Journal of Comparative Physiology B 179, 1-56.

Sepulveda, C. \& Dickson, K. A. (2000). Maximum sustainable speeds and cost of swimming in juvenile kawakawa tuna (Euthynnus affinis) and chub mackerel (Scomber japonicus). Journal of Experimental Biology 203, 3089-3101.

Sloman, K. A., Motherwell, G., O'Connor, K. I. \& Taylor, A. C. (2000). The effect of social stress on the standard metabolic rate (SMR) of brown trout. Fish Physiology and Biochemistry 23, 49-53.

Soofiani, N. M. \& Priede, I. G. (1985). Aerobic metabolic scope and swimming performance in juvenile cod, Gadus morhua L. Journal of Fish Biology 26, 127-138. doi: 10.1111/j.1095-8649.1985.tb04249.x

Steffensen, J. F. (1984). An automated swimming respirometer. Comparative Physiology and Biochemistry A 79, 437-440.

Steffensen, J. F. (1989). Some errors in respirometry of aquatic breathers: how to avoid them and correct for them. Fish Physiology and Biochemistry 6, 49-59.

Steffensen, J. F. (2002). Metabolic cold adaptation of polar fish based on measurements of aerobic oxygen consumption: fact or artefact? Artefact! Comparative Physiology and Biochemistry A 132, 789-795.

Steffensen, J. F., Bushnell, P. G. \& Schurmann, H. (1994). Oxygen consumption in four species of teleosts from Greenland: no evidence of metabolic cold adaptation. Polar Biology 14, 49-54.

Steinhausen, M. F., Steffensen, J. F. \& Andersen, N. A. (2005). Tail beat frequency as a predictor of swimming speed and oxygen consumption of saithe (Pollachius virens) and whiting (Merlangius merlangus) during forced swimming. Marine Biology 148, 157-204.

Taylor, D. L. \& Peck, M. A. (2004). Daily energy requirements and trophic positioning of the sand shrimp Crangon septemspinosa. Marine Biology 145, 167-177.

Underwood, A. J. (2002). Experiments in Ecology: Their Logical Design and Interpretation Using Analysis of Variance. New York, NY: Cambridge University Press.

Vetter, R. D. (1982). Seasonal metabolic compensation in sympatric seatrout: adaptation to the estuary. Transactions of the American Fisheries Society 111, 193-198.

Videler, J. J. (1993). Fish Swimming. London: Chapman \& Hall.

Waggy, G. L., Brown-Peterson, N. J., Patterson, M. S. (2006). Evaluation of the reproductive life history of the Sciaenidae in the Gulf of Mexico and Caribbean Sea: "greater" vs. "lesser strategies"? Proceedings of the 57th Gulf Caribbean Fisheries Institute 57, $263-282$.

White, C. R., Phillips, N. F. \& Seymour, R. S. (2006). The scaling and temperature dependence of vertebrate metabolism. Biology Letters 2, 125-127.

Winberg, G. G. (1956). Rate of metabolism and food requirements of fishes. Journal of the Fisheries Research Board of Canada Translation Series 194.

Wuenschel, M. J., Werner, R. G. \& Hoss, D. E. (2004). Effect of body size, temperature, and salinity on the routine metabolism of larval and juvenile spotted seatrout. Journal of Fish Biology 64, 1088-1102. doi: 10.1111/j.1095-8649.2004.00374.x 